\title{
TECHNICAL EVALUATION OF ARTIFICIAL LIGTHING SYSTEMS FOR BROILER HOUSES
}

\section{PRISCILLA A. PEREIRA ${ }^{1}$, TADAYUKI YANAGI JUNIOR ${ }^{2}$, JOAQUIM P. DA SILVA ${ }^{3}$, RENATO R. DE LIMA ${ }^{4}$, ALESSANDRO T. CAMPOS ${ }^{5}$, LUCAS H. P. ABREU ${ }^{6}$}

\begin{abstract}
The spatial distribution of illuminance and the electric consumption of artificial lighting system is one of the main problems related to broiler production. Therefore, the aim of this study was to evaluate the spatial distribution of luminance level and energy efficiency of different lighting systems for broiler houses. Six types of lamps were tested in two different configurations to find the minimum illuminance of 20 and 5 lux. The tested lamps were incandescent (IL) $100 \mathrm{~W}$, compact fluorescent (CFL) $34 \mathrm{~W}$, mixed (ML) $160 \mathrm{~W}$, sodium vapor (SVL) $70 \mathrm{~W}$, T8 fluorescent tube (T8 FTL) $40 \mathrm{~W}$ and T5 fluorescent tube (T5 FTL) $28 \mathrm{~W}$. The first four were evaluated with and without reflective light fixture and the latter two without light fixture. It was observed that the tested system with light fixtures negatively affected the spatial distribution of illuminance inside the house. The systems composed by IL and ML without light fixture led to better results in meeting the minimum illuminance of 20 lux and 5 lux, respectively. T5 FTL presented the lowest energy demand.
\end{abstract}

KEY WORDS: artificial lighting, spatial variability, energy efficiency, aviculture.

\section{AVALIAÇÃO TÉCNICA DE SISTEMAS DE ILUMINAÇÃO PARA GALPÕES DE FRANGOS DE CORTE}

RESUMO: A distribuição espacial das iluminâncias e o consumo de energia elétrica do sistema de iluminação artificial constituem um dos principais problemas relacionados à produção de frangos de corte. Portanto, objetivou-se com o presente trabalho avaliar a distribuição espacial do nível de iluminância e a eficiência energética de diferentes sistemas de iluminação para galpões para criação de frangos de corte. Seis tipos de lâmpadas foram testados em duas configurações diferentes para atender às iluminâncias mínimas de 20 e 5 lux. As lâmpadas testadas foram a incandescente (LI) de $100 \mathrm{~W}$, fluorescente compacta (LFC) de $34 \mathrm{~W}$, mista (LM) de $160 \mathrm{~W}$, vapor de sódio (LVS) de 70 W, fluorescente tubular T8 (LFT T8) de $40 \mathrm{~W}$ e fluorescente tubular T5 (LFT T5) de $28 \mathrm{~W}$. As quatro primeiras foram avaliadas sem e com luminária reflexiva tipo prato, e as duas últimas apenas sem luminária. Para os sistemas testados, verificou-se que o uso de luminárias afetou negativamente a distribuição espacial das iluminâncias no interior do galpão. Os sistemas compostos por LI e LM, sem luminária, propiciaram melhores resultados para se atenderem as iluminâncias mínimas de 20 lux e 5 lux, respectivamente. A LFT T5 apresentou os menores valores de demanda de energia.

PALAVRAS-CHAVE: iluminação artificial, variabilidade espacial, eficiência energética, avicultura.

\footnotetext{
${ }^{1}$ Arquiteta, Mestre em Engenharia Agrícola, área de concentração Construções e Ambiência, Departamento de Engenharia, Universidade Federal de Lavras (DEG/UFLA), Lavras - MG.

${ }^{2}$ Professor Associado, Setor de Construções e Ambiência, Departamento de Engenharia, Universidade Federal de Lavras (DEG/UFLA). Membro do Grupo de Pesquisa em Construções e Ambiência em Biossistemas (COAMBI).

${ }^{3}$ Professor Associado, Departamento de Ciências Exatas, Universidade Federal de Lavras (DEX/UFLA).

${ }^{4}$ Professor Associado, Departamento de Ciências Exatas, Universidade Federal de Lavras (DEX/UFLA).

${ }^{5}$ Professor Adjunto, Setor de Construções e Ambiência, Departamento de Engenharia, Universidade Federal de Lavras (DEG/UFLA). Coordenador do Grupo de Pesquisa em Construções e Ambiência em Biossistemas (COAMBI).

${ }^{6}$ Graduando em Engenharia Agrícola, Departamento de Engenharia, Universidade Federal de Lavras (DEG/UFLA), Lavras - MG.

Recebido pelo Conselho Editorial em: 20-1-2012

Aprovado pelo Conselho Editorial em: 9-7-2012
} 


\section{INTRODUCTION}

Lighting is an important environmental factor that affects the production of animals by interfering with their physiological and behavioral responses. Its influence covers various bodily functions and features of the animals as it controls biological rhythms such as feeding, breeding, hormone concentrations, enzyme activities and metabolic processes among others (BAETTA \& SOUZA, 2010).

Light intensity affects the behavior of broilers (KRISTENSEN et al. 2007; ALVINO et al., 2009). Besides this, other illumination aspects such as photoperiod, light source, wavelength, spectral distribution and spatial distribution of the lamps in the shed affect the quantity and quality of production (BUYSE \& SIMONS, 1996; LEWIS \& MORRIS, 1998). According to LEWIS et al. (2007), the lack of exposure to ultraviolet rays (UV) for birds kept in a controlled environment can be detrimental to their physiology and behavior. Different from man, birds have sensitivity and ability to see in this spectral range of light radiation.

Therefore, as it is related to the development and health of birds, proper lighting helps to achieve better zootechnical and economic results from this activity (MORAES et al., 2008, KAWACHI et al., 2008), and also has possibility of reducing the electricity consumption.

In this context, evaluation, followed by an appropriate design of lighting systems for broiler houses is essential for the proper performance of birds. Among the methods for analysis, there is geostatistics, which enables the study of spatial variability in the level of luminance in the houses through kriging interpolation. Thus it is possible to obtain contour maps to understand the spatial distribution which aids in the planning and control of lighting (YANAGI JUNIOR et al., 2011, FARIA et al. 2008; MIRAGLIOTTA et al., 2006).

According to YANAGI JUNIOR et al. (2011), the spatial distribution of the variables related to the production environment provides the obtainment of more detailed information about the studied system, and, with geostatistics analysis it is possible to predict values at un-sampled points in addition to the obtainment of semivariogram models and their parameters (GOMES et al., 2007).

In addition, lighting is an important factor when reducing energy consumption. According to data from the MME (2009), Brazil's energy consumption in 2007 was $412,130 \mathrm{GWh}, 17 \%$ of this total refers to artificial lighting (MME, 2007). The share of electricity consumption for lighting in the agricultural sector was 3.4\% (MME, 2007).

In poultry houses, the electricity consumption by feeding equipment, lighting and climatization are of great importance in the composition of production costs (BUENO \& ROSSI, 2006). In poultry production chain, the energy is the second most used input, where feed is the first. The lighting of the building, in most cases, is responsible for major loss (JORDAN \& TAVARES, 2005). TURCO et al. (2002), by measuring the energy consumption of equipment (feeders, fans and lamps) of a poultry house, during 40 days, during the winter, found out that $55 \%$ of the total energy consumed was due to the lighting system.

The objective of this study was to evaluate the spatial distribution of the level of iluminance and energy efficiency of different lighting systems for broiler houses.

\section{MATERIAL E METHODS}

To evaluate lighting systems for broiler houses to lower power consumption and appropriate luminance levels, six types of lamps were tested, with and without light fixture, and in two different configurations, needed for different stages of the bird's life. According to BROODING FUNDAMENTALS GUIDE (2009), for 0-3 days old Cobb broilers chickens the luminance should be 20-60 lux, for 4-7, 20 lux, for 8-14, 10 lux and for 15-28, 5 lux. In turn, the BROODING MANAGEMENT GUIDE (2009) recommends 25 lux for chicks up to seven days; thereafter the intensity should gradually be reduced from 10 to 5 lux and 48 hours before slaughter it is 
recommend an increased of 10-20 lux. OLANREWAJU et al. (2006) suggests 20 lux for the first 13 days and 5 lux until the slaughter. Similarly, RUTZ \& BERMUDEZ (2004) recommend 20 lux for the first six days, and then to slaughter the lighting must be 5 lux.

The criterion for selection of lamps and luminaires evaluated based on the usability in commercial sheds for breeding of broilers and economic viability.

The tested lamps were: incandescent (IL) $100 \mathrm{~W}$, compact fluorescent (CFL) $34 \mathrm{~W}$, mixed (ML) $160 \mathrm{~W}$, sodium vapor (SVL) $70 \mathrm{~W}$, T8 fluorescent tube (T8 FTL) $40 \mathrm{~W}$, T5 fluorescent tube (T5 FTL) $28 \mathrm{~W}$. The SVL and T5 FTL and T8 FTL lamps were equipped with electronic ballasts with power factor greater than 0.92 .

The first four were evaluated with and without reflective light fixture type plate, and the last two only without the light fixture. The configurations of lighting systems evaluated are specified in Table 1.

TABLE 1. Configuration of evaluated lighting systems regarding the presence of light fixture, number of lamp lines, spacing between them $\left(D_{\text {lines }}\right)$, distance between lamps $\left(D_{\text {lamp }}\right)$, minimum luminance and total number of lamps evaluated.

\begin{tabular}{|c|c|c|c|c|c|c|c|}
\hline \multicolumn{2}{|c|}{$\begin{array}{l}\text { Lighting } \\
\text { System }\end{array}$} & Lamp lines & $\begin{array}{l}\text { Light } \\
\text { fixture }\end{array}$ & $\begin{array}{c}\text { Minimum } \\
\text { illuminance(lux) }\end{array}$ & $\begin{array}{c}\mathrm{D}_{\text {lines }} \\
(\mathrm{m})\end{array}$ & $\begin{array}{c}\mathrm{D}_{\text {lamp }} \\
(\mathrm{m})\end{array}$ & $\begin{array}{c}\text { Total de } \\
\text { lamps }\end{array}$ \\
\hline \multirow{4}{*}{ IL } & 20lux,fa & 3 & No & 20 & 4 & 4 & 6 \\
\hline & 20lux,fp & 3 & Yes & 20 & 4 & 5 & 6 \\
\hline & 5lux,fa & 2 & No & 5 & 8 & 4 & 4 \\
\hline & 5lux,fp & 2 & Yes & 5 & 8 & 5 & 4 \\
\hline \multirow{4}{*}{ CFL } & 20lux,fa & 3 & No & 20 & 4 & 8 & 6 \\
\hline & 20lux,fp & 3 & Yes & 20 & 4 & 8 & 6 \\
\hline & 5lux,fa & 2 & No & 5 & 8 & 8 & 4 \\
\hline & 5lux,fp & 2 & Yes & 5 & 8 & 8 & 4 \\
\hline \multirow{4}{*}{ ML } & 20lux,fa & 3 & No & 20 & 4 & 7 & 6 \\
\hline & 20lux,fp & 3 & Yes & 20 & 4 & 7 & 6 \\
\hline & 5lux,fa & 2 & No & 5 & 8 & 7 & 4 \\
\hline & 5lux,fp & 2 & Yes & 5 & 8 & 7 & 4 \\
\hline \multirow{4}{*}{ SVL } & 20lux,fa & 2 & No & 20 & 6 & 10 & 4 \\
\hline & 20lux,fp & 2 & Yes & 20 & 6 & 10 & 4 \\
\hline & 5lux,fa & 2 & No & 5 & 6 & 20 & 2 \\
\hline & 5lux,fp & 2 & Yes & 5 & 6 & 20 & 2 \\
\hline T8 & 20lux,fa & 2 & No & 20 & 6 & 6 & 4 \\
\hline TFL & 5lux,fa & 2 & No & 5 & 6 & 12 & 2 \\
\hline T5 & 20lux,fa & 2 & No & 20 & 6 & 6 & 4 \\
\hline TFL & 5lux,fa & 2 & No & 5 & 6 & 12 & 2 \\
\hline
\end{tabular}

Data collection was divided into two steps. The first was conducted in an experimental shed like those used to grown broilers. A limited region of this experimental shed had the following dimensions: $10 \mathrm{~m}$ width, $36 \mathrm{~m}$ length and 3.6 in column height. The structural characteristics are as follows: gable roof with French-type ceramic shingles, a slope of $16.70^{\circ}$ with regard to the horizontal plane and $1.3 \mathrm{~m}$ overhang.

The lighting systems were installed at a height of $2.35 \mathrm{~m}$, similar to those used in some broiler houses. The criterion adopted to define the distance between the lamps was the supply of desired minimum illuminance ( 5 or 20 lux) where it was considered as critical points (points B, C, F and G of Figure 1) to obtain the minimum value required. Considering the overlap of the luminous flux, these are the points with lower levels of luminance in the experimental plot (Figure 1). No 
theoretical method for calculating light levels was adopted as literature reports some inconsistency between the data measured and estimated (DAVID, 2007; JORDAN \& TAVARES, 2005). When using IL, CFL and ML lamps, three lines of lamps were required to meet minimum illuminance of 20 lux. To provide a minimum of 5 lux, the central line was turned off. When using the SVL, T8 and T5 TFL only two lines were needed for the first scenario, and one lamp (interleaved) of each line was turned off to meet a minimum of 5 lux.

The collection of these data was performed at night to avoid interference from natural light. The luminance was measured with a single digital light-meter (ICEL, model LD-510, accuracy \pm $3 \%$ for incandescent lamps and $\pm 5 \%$ for the other) at the height of $0.30 \mathrm{~m}$ from the floor in a grid of points at every 1 meter, in three replicates made in sequence. The sampling area was determined to reach the established minimum illuminance (Points $\mathrm{E}$ and $\mathrm{H}$ in Figure 1). Based on the experimental data of luminance, the total number of lamps in a hypothetical commercial broiler house was determined, and the spatial distribution of luminance levels was simulated through the geostatistics techniques.

A.

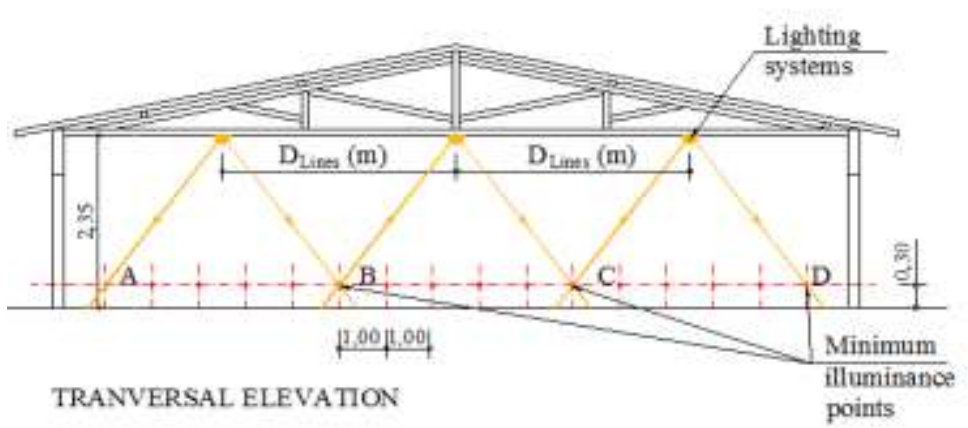

B.

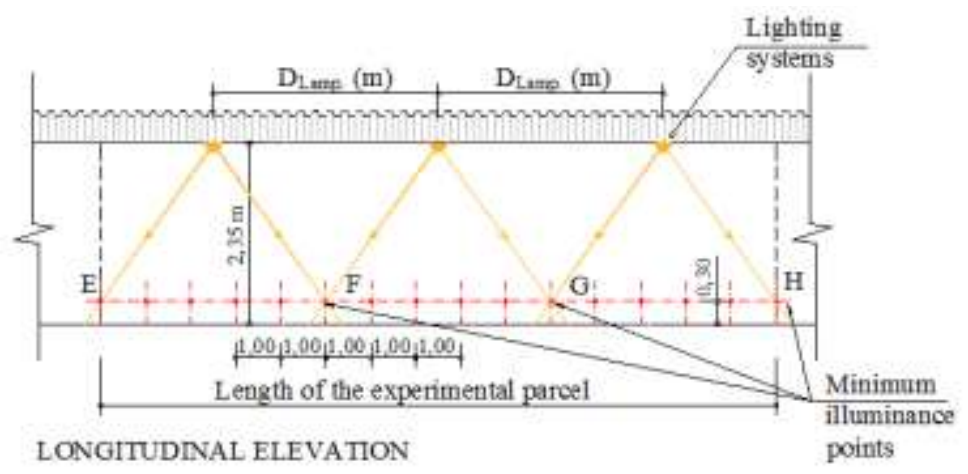

FIGURE 1. Sketch of transversal (A) and longitudinal (B) elevations with the scheme used to determine the distances between the lamps.

In the second stage of data collection the parameters referring to energy consumption of the systems were measured. The same lamps used in the first stage were installed on a laboratory workbench. With an energy analyzer (Fluke 435 , accuracy $\pm 0.03 \%$ for power factor, $\pm 0.1 \%$ for voltage and $\pm 0.5 \%$ for current) the voltage (V, V), current (I, A ) and power factor (dimensionless) were measured. From these data and the number of lamps previously, the estimated active demands $(\mathrm{P}, \mathrm{W})$, reactive $(\mathrm{Q}, \mathrm{Var})$ and apparent $(\mathrm{S}, \mathrm{VA})$ were calculates for a commercial broiler house.

There were three replications for each set of lamps assessed, with each test lasting 30 minutes. From these data and the number of lamps calculated in step 1 was performed to evaluate the total energy parameters considering a commercial broiler house.

\section{RESULTS E DISCUSSION}

Results of descriptive statistical analysis of the data are listed in Table 2. The results indicate large variability in the lighting distribution, reinforcing the need to characterize the spatial 
distribution of illuminance using geostatistics. The ideal lighting levels vary according to the bird's age. According to COBB-VANTRESS (2009a), 0-3 days should be 20 to 60 lux, 4-7, 20 lux, 8 to 14, 10 lux and 15 to 28, 5 lux. In turn, COBB-VANTRESS (2009b) recommends 25 lux for chicks up to 7 days old, thereafter the intensity should be decreased gradually from 10 to 5 lux, and $48 \mathrm{~h}$ prior to slaughter should be increased from 10 to 20 lux. OLANREWAJU et al. (2006) suggest 20 lux for the first 13 days and 5 lux until slaughter. RUTZ \& BERMUDEZ (2004) recommend 20 lux for the first 6 days, and then until slaughter the lighting must be 5 lux.

Through Table 3, it is observed that the spatial dependence of luminance and the range parameter indicates the effect radius of each system. The sodium vapor lamp had a wider range, indicating that it is necessary to use fewer units in the shed. This result is consistent with studies conducted by JÁCOME (2009) and JORDAN \& TAVARES (2005), which compared different types of artificial lighting for egg laying production. When evaluating lighting technologies for the production of chrysanthemum cuttings, DAVID \& ROSSI (2010) also used fewer sodium vapor lamps than other treatments.

TABLE 2. Mean, mediun, minimum, maximum, variance and standard deviation for the illuminance values (lux) from the evaluated lighting systems.

\begin{tabular}{|c|c|c|c|c|c|c|c|}
\hline \multirow{2}{*}{\multicolumn{2}{|c|}{ Lighting System }} & \multicolumn{6}{|c|}{ Illuminance (lux) } \\
\hline & & Mean & Medium & Minimum & Maximum & Variance & Deviation \\
\hline \multirow{4}{*}{ IL } & 20lux,fa & 33.4 & 32.0 & 14.0 & 53.0 & 65.2 & 8.1 \\
\hline & 20lux,fp & 45.4 & 38.0 & 9.0 & 135.0 & 519.4 & 22.8 \\
\hline & 5lux,fa & 21.3 & 21.0 & 3.0 & 45.0 & 95.5 & 9.8 \\
\hline & 5lux,fp & 32.6 & 28.0 & 5.0 & 139.3 & 646.0 & 25.4 \\
\hline \multirow{4}{*}{ CFL } & 20lux,fa & 37.9 & 35.0 & 17.0 & 84.0 & 181.6 & 13.5 \\
\hline & 20lux,fp & 53.5 & 47.0 & 20.7 & 136.0 & 764.7 & 27.7 \\
\hline & 5lux,fa & 25.7 & 20.0 & 9.0 & 70.0 & 156.2 & 12.5 \\
\hline & 5lux,fp & 37.1 & 26.0 & 10.0 & 121.0 & 660.1 & 25.7 \\
\hline \multirow{4}{*}{ ML } & 20lux,fa & 29.4 & 26.7 & 13.0 & 56.0 & 74.0 & 8.6 \\
\hline & 20lux,fp & 49.7 & 41.3 & 15.0 & 143.0 & 683.9 & 26.2 \\
\hline & 5lux,fa & 17.7 & 16.0 & 4.0 & 45.0 & 40.2 & 6.3 \\
\hline & 5lux,fp & 33.5 & 24.0 & 5.0 & 116.0 & 559.9 & 23.7 \\
\hline \multirow{4}{*}{ SVL } & 20lux,fa & 46.2 & 40.0 & 21.0 & 98.0 & 427.8 & 20.7 \\
\hline & 20lux,fp & 82.3 & 50.0 & 16.7 & 448.0 & 6459.1 & 80.4 \\
\hline & 5lux,fa & 20.6 & 12.0 & 4.0 & 79.0 & 329.20 & 18.1 \\
\hline & 5lux,fp & 39.2 & 12.0 & 2.0 & 400.0 & 4351.1 & 66.0 \\
\hline \multirow{2}{*}{ T8 TFL } & 20lux,fa & 36.2 & 29.0 & 12.0 & 94.0 & 340.3 & 18.4 \\
\hline & 5lux,fa & 17.2 & 10.0 & 1.7 & 89.7 & 325.6 & 18.0 \\
\hline \multirow{2}{*}{ T5 TFL } & 20lux,fa & 39.1 & 31.3 & 15.0 & 102.0 & 353.8 & 18.8 \\
\hline & 5lux,fa & 18.9 & 12.0 & 2.0 & 93.7 & 316.8 & 17.8 \\
\hline
\end{tabular}

Note: fa means fixture absence and fp is fixture presence.

An important aspect worth noting about the semivariogram parameters concerns the value of the nugget effect. The nugget effect measures the unexplained spatial variability between the shortest distance sampled (DIGGLE \& RIBEIRO JR, 2007). In this case, it is clear that the vast majority of lighting systems presented the value for nugget effect equal to zero, showing that all spatial variability could be explained. This fact should be highlighted, because usually this value is obtained only theoretically.

However, in all cases, the nugget effect showed a value lower than $25 \%$ of the value obtained for the level $\left(C_{0} / C\right)$. According to CRESSIE \& HARTFIELD (1996), this indicates a strong spatial dependence on the studied variable. 
TABLE 3. Estimates of experimental semivariogram parameter for the variable illuminance level in the evaluated lighting systems.

\begin{tabular}{|c|c|c|c|c|c|c|}
\hline \multirow{2}{*}{\multicolumn{2}{|c|}{ Lighting System }} & \multirow{2}{*}{ Model } & \multicolumn{4}{|c|}{ Semivariogram Parameter } \\
\hline & & & Nugget effect $\left(\mathrm{C}_{0}\right)$ & Reach (a) & Level (C) & ${ }^{1} \mathrm{C}_{0} / \mathrm{C}$ \\
\hline \multirow{4}{*}{ IL } & 20lux,fa & Gaussian & 0.00 & 1.89 & 54.39 & 0.00 \\
\hline & 20lux,fp & Gaussian & 0.00 & 1.94 & 555.31 & 0.00 \\
\hline & 5 lux,fa & Gaussian & 0.00 & 3.60 & 106.04 & 0.00 \\
\hline & 5lux,fp & Gaussian & 0.00 & 2.40 & 688.61 & 0.00 \\
\hline \multirow{4}{*}{ CFL } & 20lux,fa & Gaussian & 0.00 & 4.70 & 265.84 & 0.00 \\
\hline & 20lux,fp & Gaussian & 0.00 & 4.11 & 1033.39 & 0.00 \\
\hline & 5lux,fa & Gaussian & 0.00 & 4.20 & 200.78 & 0.00 \\
\hline & 5lux,fp & Gaussian & 0.00 & 2.76 & 668.38 & 0.00 \\
\hline \multirow{4}{*}{ ML } & 20lux,fa & Gaussian & 0.00 & 4.24 & 100.57 & 0.00 \\
\hline & 20lux,fp & Spherical & 0.00 & 4.38 & 894.20 & 0.00 \\
\hline & 5lux,fa & Gaussian & 0.00 & 3.58 & 49.17 & 0.00 \\
\hline & 5lux,fp & Gaussian & 0.00 & 3.24 & 671.16 & 0.00 \\
\hline \multirow{4}{*}{ SVL } & 20lux,fa & Gaussian & 22.60 & 5.14 & 576.43 & 0.04 \\
\hline & 20lux,fp & Gaussian & 0.00 & 3.33 & 7257.13 & 0.00 \\
\hline & 5lux,fa & Gaussian & 11.22 & 6.14 & 483.03 & 0.02 \\
\hline & 5lux,fp & Gaussian & 332.21 & 4.23 & 4755.96 & 0.07 \\
\hline \multirow[t]{2}{*}{ T8 TFL } & 20lux,fa & Gaussian & 0.00 & 3.64 & 523.57 & 0.00 \\
\hline & 5lux,fa & Gaussian & 0.00 & 4.05 & 406.67 & 0.00 \\
\hline \multirow{2}{*}{ T6 TFL } & 20lux,fa & Gaussian & 0.00 & 3.89 & 530.32 & 0.00 \\
\hline & 5lux.fa & Gaussian & 0.00 & 4.25 & 405.61 & 0.00 \\
\hline
\end{tabular}

${ }^{1} C_{0} / C=$ Level of spatial dependence. Note: fa means fixture absence and fp is fixture presence.

The evaluated systems with light fixtures had lower range when compared to those without the apparatus. Therefore, despite the benefits offered by such luminaries as the direction of the luminous flux down, and decrease of its depreciation due to a reduced accumulation of dirt on the lamps, these systems have reduced the range of the lighting system. This behavior is illustrated in Figure 2. Another factor observed in this figure is the higher occurrence of high levels of luminance on systems that have light fixtures.

Figure 3 depicts the frequency of occurrences of the luminance levels from the evaluated systems, clearly illustrating the differences between systems with and without light fixtures. Systems equipped with light fixtures showed less uniformity and higher frequency of luminance above the ideal. JORDAN \& TAVARES (2005) report that situations like this can be detrimental to broiler production, favoring the development of aggressive behavior, hyperactivity and cannibalism, and also causing fat deposition, higher incidence of leg problems, metabolic and circulatory diseases. JÁCOME (2009) observed a lower egg production when hens were exposed to high illuminance. OWADA et al. (2007), using the fuzzy sets theory, estimated that luminance close to 1 lux would be ideal for the welfare of broilers, between 1 and 5 lux would be viable, and other situations would not be considered great. 

A.

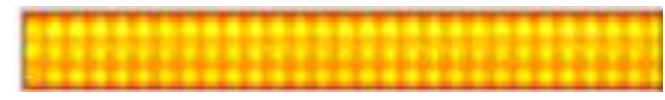
B.

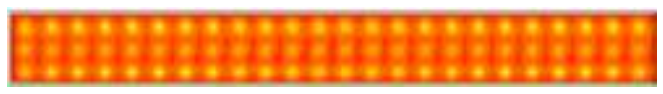

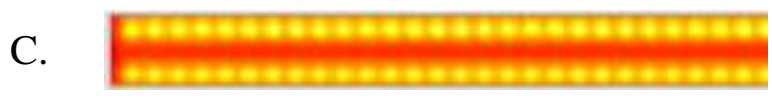
D.

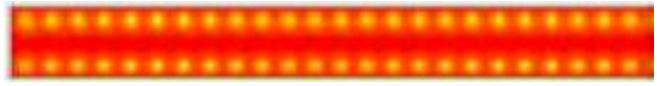
E.

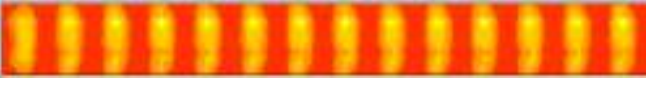
F.
G.

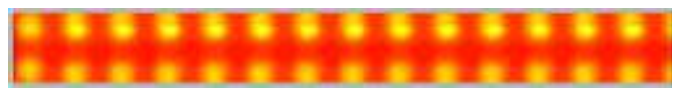
$\mathrm{H}$.

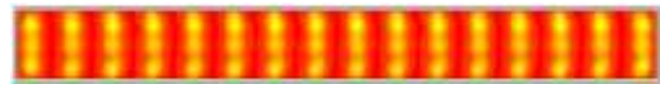
I.

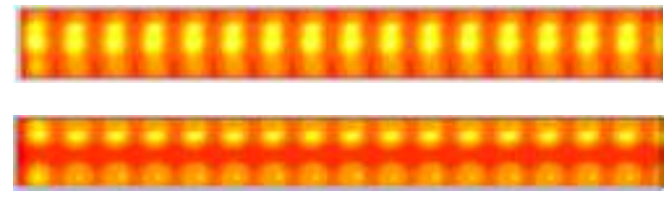
J.

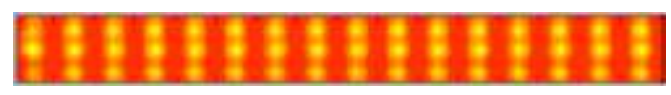
K.

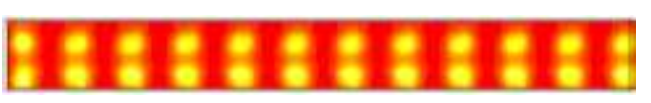
L.

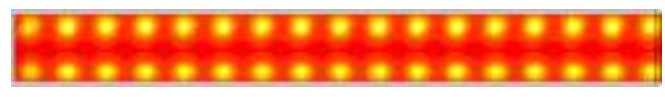
M.

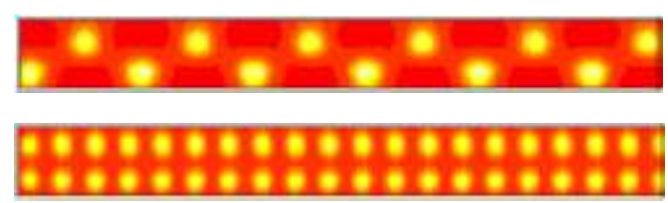
N.

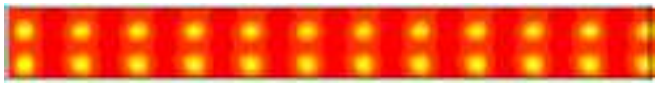

\section{o.}

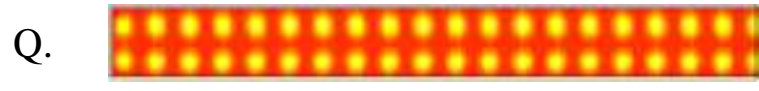
S.

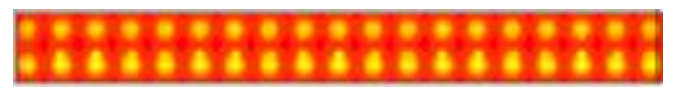

\section{P.}
$\mathrm{R}$.
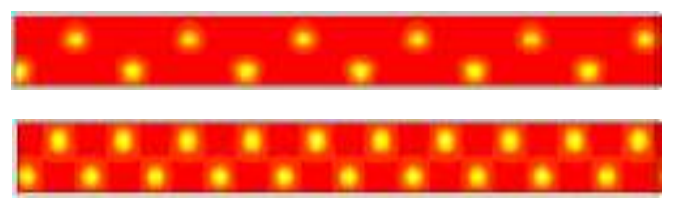
$\mathrm{T}$.

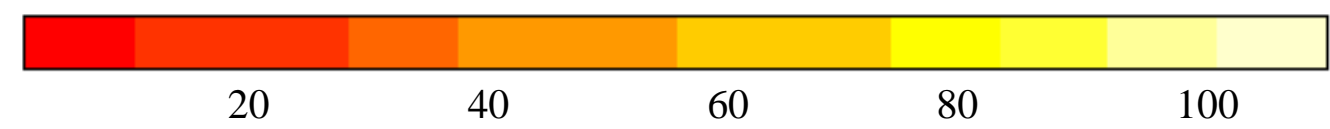

FIGURE 2. Spatial distribution of illuminance levels for the evaluated lighting systems within broiler houses: with incandescent lamps (A) $\mathrm{IL}_{20 l u x, f a}$; (B) $\mathrm{IL}_{20 l u x, f \mathrm{f}}$; (C) $\mathrm{IL}_{5 l u x, f a}$; (D) $\mathrm{IL}_{5 l u x, f \mathrm{f}}$; with compact fluorescent lamps (E) $\mathrm{CFL}_{20 l u x, f a}$; (F) $\mathrm{CFL}_{20 \mathrm{lux}, \mathrm{fp}}$; (G)

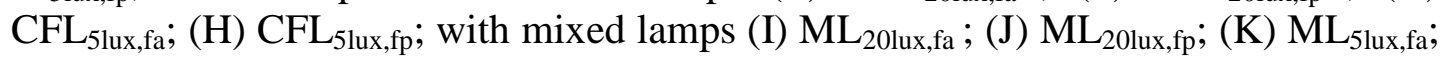
(L) ML 5 llux,fp; with sodium vapor lamps (M) $\mathrm{SVL}_{201 \mathrm{ux}, \mathrm{fa}} ;(\mathrm{N}) \mathrm{SVL}_{20 l u x, \mathrm{fp}}$; (O) SVL $\mathrm{SLlux,fa}_{\text {; }}$; (P) SVL 5 llux,fp; 78 tubular fluorescent lamp (Q) T8 TFL 20lux,fa; (R) T8 TFL 5 lux,fa; and T5 tubular fluorescent lamp (S) T5 TFL 20lux,fa; (T) T5 TFL 5lux,fa.

Note: fa means fixture absence and fp is fixture presence.

A

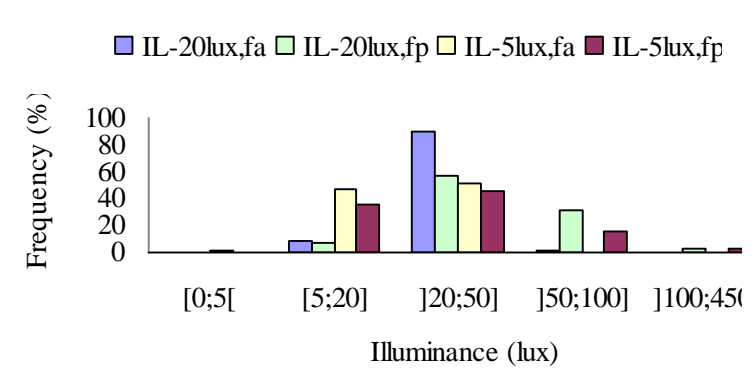

C

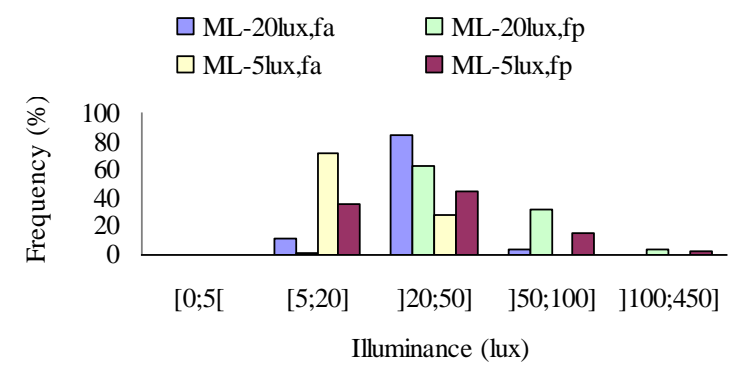

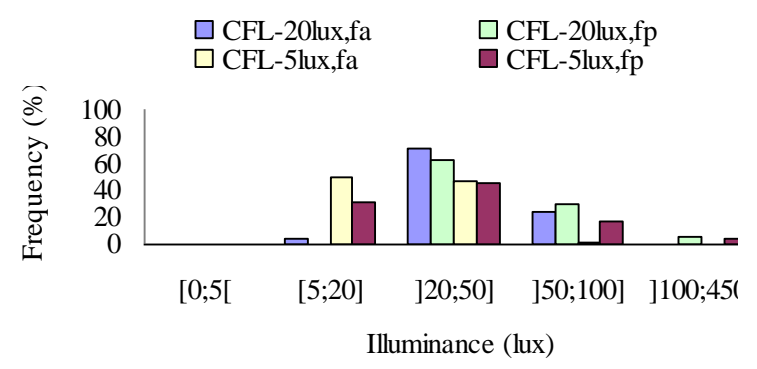

$\mathrm{D}$

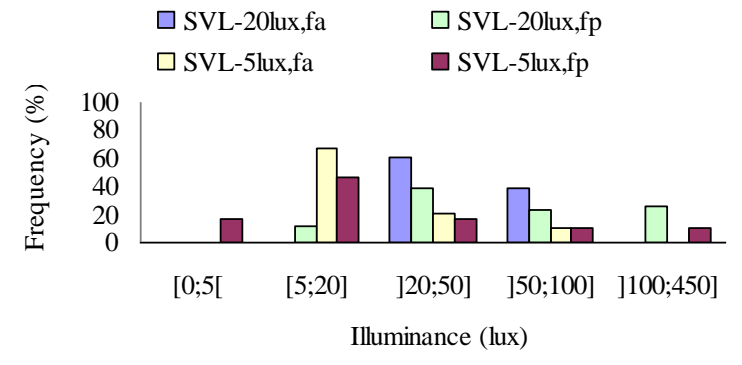


E.

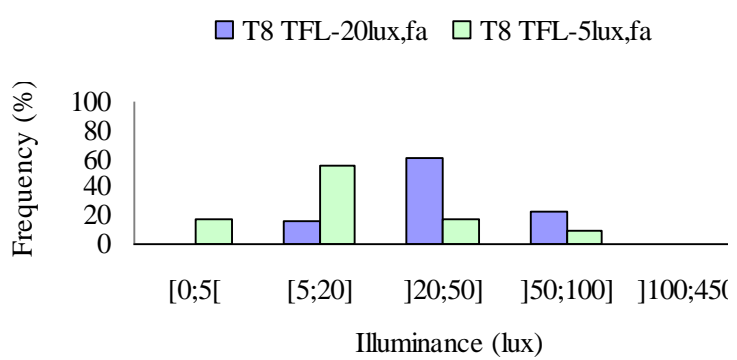

F

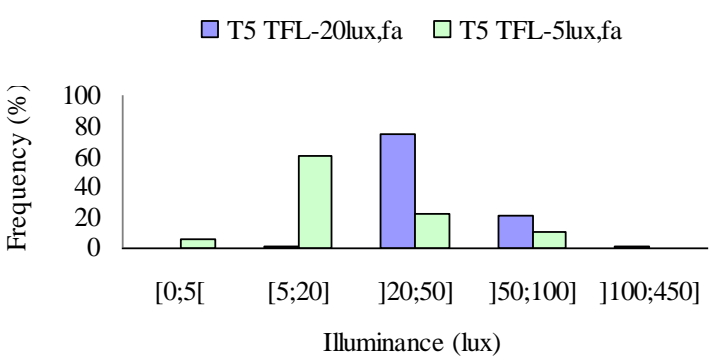

FIGURE 3. Frequency of illuminance levels occurrence inside a poultry house for the lighting systems (A) with incandescent lamps $\mathrm{IL}_{20 l u x, f a}, \mathrm{IL}_{20 l u x, f \mathrm{f}}$, $\mathrm{IL}_{5 l u x, f a}$ and $\mathrm{IL}_{5 l u x, f \mathrm{f}}$; (B) with compact fluorescent lamps $\mathrm{CFL}_{20 l u x, f a}, \mathrm{CFL}_{201 \mathrm{lux}, \mathrm{fp}}, \mathrm{CFL}_{5 \text { lux,fa }}$ and $\mathrm{CFL}_{5 \text { lux,fp }}(\mathrm{C})$ with mixed lamps $\mathrm{ML}_{20 l u x, f a}, \mathrm{ML}_{20 l u x, f \mathrm{f}}, \mathrm{ML}_{5 \text { lux,fa }}$ and $\mathrm{ML}_{5 \text { lux,fp; }}$ (D) with sodium vapor lamps $\mathrm{SVL}_{201 u x, f \mathrm{fa}}$, $\mathrm{SVL}_{20 l u x, f \mathrm{p}}, \mathrm{SVL}_{5 \mathrm{lux}, \mathrm{fa}}$ and $\mathrm{SVL}_{5 \mathrm{lux}, \mathrm{fp}}$; (E) with T8 tubular fluorescent lamp T8 $\mathrm{TFL}_{20 l u x, f a}, \mathrm{~T} 8$ $\mathrm{TFL}_{5 \text { lux,fa }}$; (F) with T5 tubular fluorescent lamp T5 TFL $201 \mathrm{lux,fa}$ and T5 TFL 5 lux,fa.

Note: fa means fixture absence and fp is fixture presence.

Among the systems evaluated to meet the minimum illuminance of 20 lux, the one that best represented the ideal distribution was the incandescent lamp ( $\mathrm{IL}_{20 l u x, f a}$ ), followed by mixed lamps (ML $\mathrm{MLlux,fa}_{2}$ ), $\mathrm{T} 5$ fluorescent tube ( $\mathrm{T} 5 \mathrm{TFL}$ 20lux,fa $)$, compact fluorescent $\left(\mathrm{CFL}_{20 l u x, f a}\right)$, sodium vapor $\left(\mathrm{SVL}_{20 l u x, f a}\right)$, and finally $\mathrm{T} 8$ fluorescent tube $\left(\mathrm{T} 8 \mathrm{TFL}_{20 l u x, f a}\right)$. It is observed that the best results were obtained in systems without light fixtures. For the illuminance of 5 lux, the absence of light fixtures also provided better results, according to the following sequence: mixed lamp ( $\mathrm{ML}_{5 \text { lux,fa }}$ ), sodium vapor lamp $\left(\mathrm{SVL}_{5 l u x, f a}\right), \mathrm{T} 5$ fluorescent tube (T5 TFL $\left.{ }_{5 l u x, f a}\right)$, T8 fluorescent tube (T8 TFL 5 lux,fa $)$, compact fluorescent $\left(\mathrm{CFL}_{5 \text { lux,fa }}\right)$ and incandescent lamp $\left(\mathrm{IL}_{5 \text { lux,fa }}\right)$.

In Table 4 the total numbers of lamps, voltages, currents and power factor are listed for each of the systems evaluated, simulated from the data obtained in this study. For this estimate, a commercial for broiler house was considered, with dimensions of $12 \times 125 \mathrm{~m}$, and installation of lighting systems at $2.35 \mathrm{~m}$ from the floor.

TABLE 4. Total number of lamps, voltage (V), current (A), and power factor simulated for a commercial broiler house, for the evaluated systems.

\begin{tabular}{|c|c|c|c|c|c|}
\hline \multicolumn{2}{|c|}{ Lighting System } & Lamps (total) & Voltage (V) & Current (A) & Power Factor \\
\hline \multirow{4}{*}{ IL } & 20lux,fa & 93 & 215.74 & 39.06 & 0.99 \\
\hline & 20lux,fp & 75 & 215.74 & 31.50 & 0.99 \\
\hline & 5lux,fa & 62 & 215.74 & 26.04 & 0.99 \\
\hline & 5lux,fp & 50 & 215.74 & 21.00 & 0.99 \\
\hline \multirow{4}{*}{ CFL } & 20lux,fa & 48 & 218.80 & 12.96 & 0.56 \\
\hline & 20lux,fp & 48 & 218.80 & 12.96 & 0.56 \\
\hline & $5 \operatorname{lux}, \mathrm{fa}$ & 32 & 218.80 & 8.64 & 0.56 \\
\hline & 5lux,fp & 32 & 218.80 & 8.64 & 0.56 \\
\hline \multirow{4}{*}{ ML } & 20lux,fa & 54 & 215.55 & 37.80 & 0.95 \\
\hline & 20lux,fp & 54 & 215.55 & 37.80 & 0.95 \\
\hline & $5 \operatorname{lux}, \mathrm{fa}$ & 36 & 215.55 & 25.20 & 0.95 \\
\hline & 5lux,fp & 36 & 215.55 & 25.20 & 0.95 \\
\hline \multirow{4}{*}{ SVL } & 20lux,fa & 26 & 218.53 & 11.70 & 0.86 \\
\hline & 20lux,fp & 26 & 218.53 & 11.70 & 0.86 \\
\hline & $5 \operatorname{lux}, \mathrm{fa}$ & 13 & 218.53 & 5.85 & 0.86 \\
\hline & 5lux,fp & 13 & 218.53 & 5.85 & 0.86 \\
\hline \multirow{2}{*}{ T8 TFL } & 20lux,fa & 32 & 215.26 & 6.08 & 1.00 \\
\hline & 5lux,fa & 16 & 215.26 & 3.04 & 1.00 \\
\hline \multirow{2}{*}{ T5 TFL } & 20lux,fa & 32 & 217.75 & 4.80 & 1.00 \\
\hline & 5 lux,fa & 16 & 217.75 & 2.40 & 1.00 \\
\hline
\end{tabular}

Note: fa means fixture absence and fp is fixture presence. 
For the analysis of power factor, the Agência Nacional de Energia Elétrica (ANEEL) (National Agency of Electrical Energy) considers as the minimum value allowed at 0.92. Only compact fluorescent and sodium vapor had power factor below the limit allowed. Therefore, these systems provide higher values of reactive demand, which increases the cost of generating electricity. For industrial and rural consumers, there are specific rates and charges on the reactive power consumed, justifying the adoption of equipment with power factor close to 1 . These results are similar to those observed by DAVID \& ROSSI (2010) when evaluating different types of lamps for the production of chrysanthemum cuttings. The values were 1.0 for IL, 0.56 for CFL, 0.98 for T8 TFL, 0.95 for SVL. JÁCOME (2009), testing different types of lamps for housing laying hens found 0.83 for SVL, 0.58 for CFL and 0.99 for IL.

In tables 5 and 6 these demands are listed for illuminance levels of 5 and 20 lux, respectively. IL systems without light fixtures ( $\mathrm{IL}_{20 l u x, f a}$ and $\mathrm{IL}_{5 l u x, f a}$ ) had a higher demand and therefore higher consumption and greater cost. This result is because this lamp has the characteristic of turning most of its energy into heat, and only the rest into light energy. IL systems with light fixture ( $\mathrm{IL}_{20 l u x, f p}$, $\left.\mathrm{IL}_{5 l u x, f p}\right)$ showed, however, lower demands than the ML systems $\left(\mathrm{ML}_{20 l u x, f a}, \mathrm{ML}_{20 l u x, f p}, \mathrm{ML}_{5 \text { lux,fa }}\right.$, $\mathrm{ML}_{20 l u x, f p}$ ). Therefore, for IL, the use of light fixture decreases the demand due to the smaller number of lamps used.

TABLE 5. Active (W), reactive (VAr) and Apparent (VA) demand for the evaluated systems that meet the minimum illuminance of 5 lux.

\begin{tabular}{|c|c|c|c|c|c|c|c|c|}
\hline \multicolumn{3}{|c|}{ Active demand (W) } & \multicolumn{2}{|c|}{ Reactive demand (VAr) } & & \multicolumn{3}{|c|}{ Apparent demand(Va) } \\
\hline Treatments & Average & & Treatments & Average & & Treatments & Average & \\
\hline $\mathrm{IL}_{5 \text { lux,fa }}$ & 5618.96 & $\bar{a}$ & $\mathrm{ML}_{\text {5lux,fa }}$ & 1686.13 & $\bar{a}$ & $\mathrm{IL}_{5 \text { lux,fa }}$ & 5664.05 & $\mathrm{a}$ \\
\hline $\mathrm{ML}_{5 \text { lux,fa }}$ & 5162.14 & b & $\mathrm{ML}_{5 l u x, f p}$ & 1686.13 & $\mathrm{a}$ & $\mathrm{ML}_{5 \text { lux,fa }}$ & 5439.15 & $\mathrm{~b}$ \\
\hline $\mathrm{ML}_{5 l u x, f p}$ & 5162.14 & $b$ & $\mathrm{CFL}_{5 \text { lux,fa }}$ & 1533.07 & b & $\mathrm{ML}_{5 l u x, f p}$ & 5439.15 & $\mathrm{~b}$ \\
\hline $\mathrm{IL}_{5 \text { lux,fp }}$ & 4531.41 & $\mathrm{c}$ & $\mathrm{CFL}_{5 \text { lux,fa }}$ & 1533.07 & $b$ & $\mathrm{IL}_{5 l u x, f p}$ & 4567.78 & $\mathrm{c}$ \\
\hline $\mathrm{SVL}_{51 \mathrm{lu}, \mathrm{fa}}$ & 1102.49 & d & $\mathrm{IL}_{5 \text { lux,fa }}$ & 713.67 & $\mathrm{c}$ & $\mathrm{CFL}_{5 \text { lux,fa }}$ & 1869.60 & d \\
\hline $\mathrm{SVL}_{5 l u x, f p}$ & 1102.49 & d & $\mathrm{SVL}_{5 \text { lux,fa }}$ & 652.26 & d & $\mathrm{CFL}_{5 \text { lux,fa }}$ & 1869.60 & d \\
\hline $\mathrm{CFL}_{5 \text { lux,fa }}$ & 1045.11 & d & $\mathrm{SVL}_{5 l u x, f p}$ & 652.26 & d & $\mathrm{SVL}_{5 l u x, f a}$ & 1278.95 & $\mathrm{e}$ \\
\hline $\mathrm{CFL}_{5 l u x, f p}$ & 1045.11 & d & $\mathrm{IL}_{5 \text { lux,fa }}$ & 575.54 & $\mathrm{e}$ & $\mathrm{SVL}_{5 l u x, f p}$ & 1278.95 & $\mathrm{e}$ \\
\hline T8 $\mathrm{TFL}_{5 l u x, f a}$ & 647.25 & e & T5 $^{\text {TFL }_{5 l u x, f a}}$ & 0 & $\mathrm{f}$ & $\mathrm{T} \mathrm{TFL}_{5 l u x, f a}$ & 647.25 & $\mathrm{f}$ \\
\hline T5 TFL 5 lux,fa & 527.10 & $\mathrm{f}$ & T8 TFL 5 lux,fa & 0 & $\mathrm{f}$ & T5 TFL 5 lux,fa & 527.10 & $\mathrm{~g}$ \\
\hline
\end{tabular}

Averages followed by the same letter in the column do not differ by the Scott-Knott test at $5 \%$ significance.

Note: fa means fixture absence and fp is fixture presence.

For the illuminance of 5 lux, SVL and CFL showed no significant difference in active demand, but as CFL has a lower power factor, which brings more reactive demand, SVL had a better result by presenting lower apparent demand. JORDAN \& TAVARES (2005), analyzing different types of lamps to produce fertile eggs, verified that the sodium vapor lamp $70 \mathrm{~W}$ offers major advantages, because it showed a $76 \%$ savings compared to incandescent 100W. JÁCOME (2009), comparing incandescent lamp 100W (control) with sodium vapor lamp $70 \mathrm{~W}$, found a $54.14 \%$ reduction in demand, and comparing the control with compact fluorescent lamp $23 \mathrm{~W}$, the reduction was $73.76 \%$. DAVID \& ROSSI (2010) found that replacing incandescent lamps $100 \mathrm{~W}$ with compact fluorescent lamps $23 \mathrm{~W}$ showed a $75 \%$ reduction in electricity consumption for the production of chrysanthemum cuttings, without affecting the final output.

The data in Table 6 indicate that the best results are obtained by T5 $201 \mathrm{ux}, \mathrm{fa}$ and $\mathrm{T} 8_{20 l u x, f a} \mathrm{TFL}$ systems, respectively, by presenting lower demands for electricity and higher power factor. 
TABLE 6. Active (P), reactive (Q) and apparent (S) demand for the evaluated systems that meet the minimum illuminance of 20 lux.

\begin{tabular}{|c|c|c|c|c|c|c|c|c|}
\hline \multicolumn{3}{|c|}{ Active demand (W) } & \multicolumn{2}{|c|}{ Reactive demand (VAr) } & & \multicolumn{3}{|c|}{ Apparent demand(Va) } \\
\hline Treatments & Average & & Treatments & Average & & Treatments & Average & \\
\hline $\mathrm{IL}_{20 l u x, f a}$ & 8428.43 & $\mathrm{a}$ & $\mathrm{ML}_{20 l u x, f a}$ & 2529.21 & $\mathrm{a}$ & $\mathrm{IL}_{20 l u x, f a}$ & 8496.08 & $\mathrm{a}$ \\
\hline $\mathrm{ML}_{20 l u x, f a}$ & 7743.21 & $\mathrm{~b}$ & $\mathrm{ML}_{20 l u x, f p}$ & 2529.21 & $\mathrm{a}$ & $\mathrm{ML}_{20 l u x, f a}$ & 8158.72 & $\mathrm{~b}$ \\
\hline $\mathrm{ML}_{20 l u x, f p}$ & 7743.21 & $b$ & $\mathrm{CFL}_{20 l u x, f a}$ & 2299.61 & $b$ & $\mathrm{ML}_{20 l u x, f p}$ & 8158.72 & $\mathrm{~b}$ \\
\hline $\mathrm{IL}_{20 l u x, f p}$ & 6797.12 & $\mathrm{c}$ & $\mathrm{CFL}_{20 l u x, f p}$ & 2299.61 & $\mathrm{~b}$ & $\mathrm{IL}_{20 l u x, f p}$ & 6851.68 & $\mathrm{c}$ \\
\hline $\mathrm{SVL}_{20 l u x, f a}$ & 2204.99 & d & $\mathrm{SVL}_{20 l u x, f a}$ & 1304.53 & $\mathrm{c}$ & $\mathrm{CFL}_{20 l u x . f a}$ & 2804.40 & $\mathrm{~d}$ \\
\hline $\mathrm{SVL}_{20 l u x, f p}$ & 2204.99 & d & $\mathrm{SVL}_{20 l u x, f p}$ & 1304.53 & $\mathrm{c}$ & $\mathrm{CFL}_{20 l u x, f p}$ & 2804.40 & $\mathrm{~d}$ \\
\hline $\mathrm{CFL}_{20 l u x, f a}$ & 1567.66 & $\mathrm{e}$ & $\mathrm{IL}_{20 l u x, f a}$ & 1070.51 & d & $\mathrm{SVL}_{20 l u x, f a}$ & 2557.89 & $\mathrm{e}$ \\
\hline $\mathrm{CFL}_{20 l u x, f p}$ & 1567.66 & $\mathrm{e}$ & $\mathrm{IL}_{20 l u x, f p}$ & 863.31 & e & $\mathrm{SVL}_{20 l u x, f p}$ & 2557.89 & $\mathrm{e}$ \\
\hline T8 TFL $_{20 l u x, f a}$ & 1294.51 & $\mathrm{f}$ & T8 TFL $_{20 l u x, f a}$ & 0 & $\mathrm{f}$ & T8 TFL $_{20 l u x, f a}$ & 1294.51 & $\mathrm{f}$ \\
\hline T5 TFL 201 lux,fa & 1054.19 & g & T5 TFL $201 \mathrm{ux}, \mathrm{fa}$ & 0 & $\mathrm{f}$ & T5 TFL $201 u x, f a$ & 1054.19 & $\mathrm{~g}$ \\
\hline
\end{tabular}

Averages followed by the same letter in the column do not differ by the Scott-Knott test t 5\% significance.

Note: fa means fixture absence and fp is fixture presence.

It is presented in tables 7 and 8 the values for reduction of active and apparent demand in the evaluated systems regarding treatments $\mathrm{IL} 20_{\mathrm{lux}, \mathrm{fa}}$ and $\mathrm{IL}_{5 \mathrm{lux}, \mathrm{fa}}$, which showed the highest values for these parameters. For the reactive demand the comparison was made regarding the treatment $\mathrm{ML}_{20 l u x, f a}$ and $\mathrm{ML}_{5 \text { lux,fa. }}$ The lamp that showed the best performance was a T5 fluorescent tube, followed by T8.

TABLE 7. Reduction (percentage) of the maximum electric demand, compared to the $\mathrm{IL}_{5 l u x, f a}$, which meet the minimum illuminance of 5 lux.

\begin{tabular}{|c|c|c|c|c|c|}
\hline \multicolumn{2}{|c|}{ Active demand (W) } & \multicolumn{2}{|c|}{ Reactive demand (VAr) } & \multicolumn{2}{|c|}{ Apparent demand(Va) } \\
\hline Treatments & $\%$ of reduction & Treatments & $\%$ of reduction & Treatments & $\%$ of reduction \\
\hline $\mathrm{IL}_{5 \text { lux,fa }}$ & & $\mathrm{ML}_{5 \text { lux, fa }}$ & & $\mathrm{IL}_{5 \text { lux,fa }}$ & \\
\hline $\mathrm{ML}_{5 \mathrm{lux}, \mathrm{fa}}$ & 8.13 & $\mathrm{ML}_{5 \mathrm{lux}, \mathrm{fp}}$ & 0.00 & $\mathrm{ML}_{5 \text { lux,fa }}$ & 3.97 \\
\hline $\mathrm{ML}_{5 l \mathrm{lux}, \mathrm{fp}}$ & 8.13 & $\mathrm{CFL}_{5 \text { lux,fa }}$ & 9.08 & $\mathrm{ML}_{5 l u x, f p}$ & 3.97 \\
\hline $\mathrm{IL}_{5 \text { lux,fp }}$ & 19.36 & $\mathrm{CFL}_{5 \text { lux,fa }}$ & 9.08 & $\mathrm{IL}_{5 l u x, f p}$ & 19.35 \\
\hline $\mathrm{SVL}_{5 \text { lux }, \mathrm{fa}}$ & 80.38 & $\mathrm{IL}_{5 \text { lux,fa }}$ & 57.67 & $\mathrm{CFL}_{5 \text { lux,fa }}$ & 66.99 \\
\hline $\mathrm{SVL}_{5 \text { lux,fp }}$ & 80.38 & $\mathrm{SVL}_{5 l u x, f a}$ & 61.32 & $\mathrm{CFL}_{5 \text { lux,fp }}$ & 66.99 \\
\hline $\mathrm{CFL}_{5 \text { lux,fa }}$ & 81.40 & $\mathrm{SVL}_{5 l u x, f \mathrm{p}}$ & 61.32 & $\mathrm{SVL}_{5 l u x, \mathrm{fa}}$ & 77.42 \\
\hline $\mathrm{CFL}_{5 \text { lux,fp }}$ & 81.40 & $\mathrm{IL}_{5 \text { lux,fa }}$ & 65.87 & $\mathrm{SVL}_{5 \text { lux,fp }}$ & 77.42 \\
\hline T8 TFL $_{5 l u x, f a}$ & 88.48 & T5 $\mathrm{TFL}_{5 \text { lux,fa }}$ & 100.00 & T8 $\mathrm{TFL}_{5 \mathrm{lux}, \mathrm{fa}}$ & 88.57 \\
\hline T5 TFL $_{5 l u x, f a}$ & 90.62 & T8 $\mathrm{TFL}_{5 \text { lux,fa }}$ & 100.00 & $\mathrm{~T} \mathrm{TFL}_{5 \text { lux,fa }}$ & 90.69 \\
\hline
\end{tabular}

Note: fa means fixture absence and fp is fixture presence.

TABLE 8. Reduction (percentage) of the maximum electric demand, compared to the $\mathrm{IL}_{20 l u x, f a}$ which meet the minimum illuminance of 20 lux.

\begin{tabular}{|c|c|c|c|c|c|}
\hline \multicolumn{2}{|c|}{ Active demand (W) } & \multicolumn{2}{|c|}{ Reactive demand (VAr) } & \multicolumn{2}{|c|}{ Apparent demand(Va) } \\
\hline Treatments & $\%$ of reduction & Treatments & $\%$ of reduction & Treatments & $\%$ of reduction \\
\hline $\mathrm{IL}_{20 l u x, f a}$ & & $\mathrm{ML}_{20 l u x, f a}$ & & $\mathrm{IL}_{20 l u x, f a}$ & \\
\hline $\mathrm{ML}_{20 l u x, f a}$ & 8.1 & $\mathrm{ML}_{20 l u x, f p}$ & 0.0 & $\mathrm{ML}_{20 l u x, f a}$ & 4.0 \\
\hline $\mathrm{ML}_{20 l u x, f p}$ & 8.1 & $\mathrm{CFL}_{20 l u x, f a}$ & 9.1 & $\mathrm{ML}_{20 l u x, f p}$ & 4.0 \\
\hline $\mathrm{IL}_{20 l u x, f p}$ & 19.4 & $\mathrm{CFL}_{20 l u x, f p}$ & 9.1 & $\mathrm{IL}_{20 l u x, f p}$ & 19.4 \\
\hline $\mathrm{SLV}_{20 l u x, f a}$ & 73.8 & $\mathrm{SLV}_{20 l u x, f a}$ & 48.4 & $\mathrm{CFL}_{20 l u x, f a}$ & 67.0 \\
\hline $\mathrm{SLV}_{20 l u x, f p}$ & 73.8 & $\mathrm{SLV}_{20 l u x, f p}$ & 48.4 & $\mathrm{CFL}_{20 l u x, f p}$ & 67.0 \\
\hline $\mathrm{CFL}_{20 l u x, f a}$ & 81.4 & $\mathrm{IL}_{201 \mathrm{lux}, \mathrm{fa}}$ & 57.7 & $\mathrm{SLV}_{20 l u x, f a}$ & 69.9 \\
\hline $\mathrm{CFL}_{20 l u x, f p}$ & 81.4 & $\mathrm{IL}_{20 l u x, f p}$ & 65.9 & $\mathrm{SLV}_{20 l u x, f p}$ & 69.9 \\
\hline T8 $\mathrm{TFL}_{20 l u x, f a}$ & 84.6 & T8 TFL 201 lux,fa & 100.0 & T8 TFL $_{20 l u x, f a}$ & 84.8 \\
\hline T5 TFL 201 lux,fa & 87.5 & T5 TFL $_{20 l u x, f a}$ & 100.0 & T5 TFL 201 lux,fa & 87.6 \\
\hline
\end{tabular}

Note: fa means fixture absence and fp is fixture presence. 


\section{CONCLUSIONS}

Considering the lighting configurations evaluated, the use of light fixtures provides no benefits for the production of broilers, being detrimental to the distribution of luminance, however, it should be noted that other configurations can be evaluated.

The lighting systems composed by incandescent and mixed lamps, without light fixture, led to better results for meeting the minimum illuminance of 20 lux and 5 lux, respectively.

The T5 fluorescent tube lamp was the one with the lowest energy demand, and therefore would lead to greater economic advantages due to low power consumption.

As nowadays, the efficient use of energy is primordial to the sustainability of our planet and as the luminance distribution among the lamps with best performance (incandescent, mixed lamps, sodium vapor lamp, T5 fluorescent tube lamp) was lower than $16.41 \%$ and $15.36 \%$ for 20 lux and 5 lux target, T5 fluorescent tube lamp is more indicated for use in broiler houses. However, researches should be conducted to evaluate the broiler productivity and behavior.

\section{AKNOWLEDGMENTS}

The authors express their thanks to CAPES, FAPEMIG and CNPq for the financial support.

\section{REFERENCES}

ALVINO, G.M.; ARCHER, G.S.; MENCH, J.A. Behavioural time budgets of broiler chickens reared in varying light intensities. Applied Animal Behaviour Science, Amsterdam, v.118, p.54-61, 2009.

BAÊTA, F. C.; SOUZA, C. F. Ambiência em edificações rurais: conforto animal. Viçosa: Ed. UFV, 269p. 2010.

BUENO, L. ROSSI, L. A. Comparação entre tecnologias de climatização para criação de frangos quanto a energia, ambiência e produtividade. Revista Brasileira de Engenharia Agrícola e Ambiental, Campina Grande, v.10, n.2, p.497-504, 2006.

BUYSE, J.; SIMONS, P. C. N. Effect of intermittent lighting, ligth intensity and source on the performance and welfare of broilers. World's Poultry Science Journal, Washington, v.52, p.121130, 1996.

BRASIL. Ministério de Minas e Energia. Balanço energético nacional 2009: ano base 2008. Rio de Janeiro: EPE, 2009. 276p.

BRASIL. Ministério de Minas e Energia. Plano nacional de energia 2030: eficiência energética. Brasília: EPE, 2007. 244p.

COBB-VANTRESS. Brooding fundamentals guide. 2009a. 11p. Disponível em: <http://www.cobbvantress.com/>. Acesso em: 29 ago. 2011.

COBB-VANTRESS. Brooding management guide. 2009b. Disponível em: <http://www.cobbvantress.com/>. Acesso em: 29 ago. 2011.

CRESSIE, N.; HARTFIELD, M.N. Conditionally specified gaussian model for spatial statistical analysis of field traits. Journal of Agricultural, Biological, and Environmental Statistics, Washington, v.1, n.1, p.60-77, Mar. 1996.

DAVID, E. Diferentes tecnologias de iluminação para produção de mudas de crisântemo. 2007. 86f. Dissertação (Mestrado) - Universidade Estadual de Campinas, Campinas, 2007.

DAVID, E. ROSSI, L. A. Diferentes tecnologias de iluminação para produção de mudas de crisântemo. Revista Brasileira de Engenharia Agrícola e Ambiental, Campina Grande, v.14, n.3, p.261-266, 2010. 
DIGGLE, P. J.; RIBEIRO JR, P. J. Model-based geoestatistic. New York: Springer, 2007. 230p

FARIA, F. F.; MOURA, D. J.; SOUZA, Z. M.; MATARAZZO, S. V. Variabilidade espacial do microclima de um galpão utilizado para confinamento de bovinos de leite. Ciência Rural, Santa Maria, v.38, n.9, p.2498-2505, dez. 2008.

GOMES, N. M.; FARIA, M. A.; SILVA, A. M.; MELLO, C. R.; VIOLA, M. R. Variabilidade espacial de atributos físicos do solo associados ao uso e ocupação da paisagem. Revista Brasileira de Engenharia Agrícola e Ambiental, Campina Grande, v.11, n.4, p.427-435, 2007.

JÁCOME, I. M. T. D. Diferentes sistemas de iluminação artificial usados no alojamento de poedeiras leves. 2009. 144 f. Tese (Doutorado) - Universidade Estadual de Campinas, Campinas, 2009.

JORDAN, R. A.; TAVARES, M. H. F. Análise de diferentes sistemas de iluminação para aviários de produção de ovos férteis. Revista Brasileira de Engenharia Agrícola e Ambiental, Campina Grande, v.9, n.3, p.420-423, 2005.

KAWACHI, I. M.; SAKOMURA, N. K.; BARBOSA, N. A. A.; AGUILAR, C. A. L.; MARCATO, S. M.; BONATO, M. A.; FERNANDES, J. B. K. Efeito de programas de luz sobre o desempenho e rendimento de carcaça, cortes comerciais e vísceras comestíveis de frangos de corte. ARS Veterinária, Jaboticabal, v.24, n.1, p.059-065, 2008.

KRISTENSEN, H.H.; PRESCOT, N.B.; PERRY, G.C.; LADEWG, J.; ERSBOLL, A.K.; OVERVAD, K.C.; WATHES, C.M. The behaviour of broiler chickens in different light sources and illuminances. Applied Animal Behaviour Science, Amsterdam, v.103, p.75-89, 2007.

LEWIS, P.D.; MORRIS, T.R. Responses of domestic poultry to various light sources. World's Poultry Science Journal, Washington. v.54, p.7-25, 1998.

LEWIS, P.D.; GHEBREMARIAM, W.; GOUS, R.M. Illuminance and UV-A exposure during rearing affects egg production in broiler breeders transferred to open-sided adult housing. British Poultry Science, London, v.48, p. 424-429, 2007.

MIRAGLIOTTA, M. Y.; NAAS, , I. A.; MANZIONE, R.L.; NASCIMENTO, F.F. Spatial analysis of stress conditions inside broiler house under tunnel ventilation. Sciencia Agricola, Piracicaba, v.63,n.5, p.426-432, 2006.

MORAES, D. T.; LARA, L. J. C.; BAIÃO, N. C.; CANÇADO, S. V.; GONZALEZ, M. L.; AGUILAR, C. A. L; LANA, A. M. Q. Efeitos dos programas de luz sobre o desempenho, rendimento de abate, aspectos econômicos e resposta imunológica em frangos de corte. Arquivo Brasileiro de Medicina Veterinária e Zootecnia, Belo Horizonte, v.60, n.1, p.201-208, 2008.

OLANREAWAJU, H. A.; THAXTON, J. P.; DOZIER, W. A., PURSWELL, J.; ROUSH, W. B., BRANTON, S. L. A review of lighting programs for broiler production. International Journal of Poultry Science, Parkinson, v. 5, n. 4, p. 301-308, 2006.

OWADA, A. N.; NAAS, I. A.; MOURA, D. J.; BARACHO, M. S. Estimating broiler welfare as function of ammonia concentration and light level inside housing. Engenharia Agrícola, Jaboticabal, v. 27, n.3, p. 611-618, 2007.

RUTZ, F.; BERMUDEZ, V. L. Fundamentos de um programa de luz para frangos de corte. In: MENDES, A. A.; NAS, I. A.; MACARI, M. (Ed.) Produção de frangos de corte. Campinas: Facta, 2004. p.157-168.

TURCO, J. A. P.; FERREIRA, L. F. S. A; FURLAN, R.L. Consumo e custo de energia elétrica em equipamentos utilizados em galpão de frangos de corte. Revista Brasileira de Engenharia Agrícola e Ambiental, Campina Grande, v.6, n.3, p.519-522, 2002. 
YANAGI, T.; AMARAL, A. G.; TEIXEIRA, V. H.; LIMA, R. R. Caracterização espacial do ambiente termoacústico e de iluminância em galpão comercial para criação de frangos de corte. Engenharia Agrícola, Jaboticabal, v.31, n.1, p.1-12, 2011. 